\title{
PENGARUH PEMBINAAN, DISIPLIN DAN MOTIVASI TERHADAP KINERJA GURU PAUD KEC. TALANG KELAPA
}

\author{
Dessi Andriani \\ Program Studi Pendidikan Guru Pendidikan Anak Usia Dini \\ Universitas PGRI Palembang \\ E-mail : dessiandriani @gmail.com
}

\begin{abstract}
This study aims to determine the influence between Development and Discipline either partially or simultaneously on the performance of Teachers In PAUD-PAUD in Kec. Talang Kelapa. Hypotheses submitted (1). Suspected Coaching Positively and significantly affect the performance of teachers in early childhood in the district. Talang Kelapa (2).Dispossible Displin positively and significantly influence on PAUD Teacher Performance in Kec. Talang Kelapa. (3) Positive and Real Motivation affect the performance of PAUD teachers in Kec. Talang Kelapa.

(4). Alleged Fostering Discipline and motivation jointly affect the performance of Teachers In PAUD in Kec. Talang Kelapa which amounted to 50 people, with the research sample taken all by using census technique. Instruments Data collection used is a questionnaire that uses Likert scale which is compiled based on the summarizes of the various theories embodied into operational variables, while testing on the research instrument is done through validity and reliability test. Data analysis was performed through a requirement test consisting of normality test using Smirnov kolmogrof test, homogeneity test using Chi square test, and linearity test using One-Way Anova. Hypothesis testing dilakuka by using regression analysis and correlation between the guidance and displin variable as a free variable on the performance of teachers as a dependent variable. The T-test is used to determine the effect of the three independent variables of Discipline Development and Motivation parcially on teacher performance as dependent variable. While the F-Test to determine the effect of the three independent variables Development of Displin and Motivation simultaneously on the performance of teachers as a dependent variable. Signature level used in this research is $\alpha=5 \%$. The results showed that (1). Positive and tangible coaching influences Teacher Performance in PAUD in Kec. Talang Kelapa. (2) Displin positively and significantly influence on Teacher Performance in PAUD in Kec. Talang Kelapa. (3) Motivation positively and significantly influence on PAUD Teacher Performance in Kec. Talang Kelapa. (4) Development of Discipline and Motivation together influential on Teacher Performance In PAUD in KEC. Talang Kelapa.
\end{abstract}

Key Words: Performance of early childhood teachers, coaching, discipline, motivation, Talang Kelapa sub-district

\begin{abstract}
Abstrak:Penelitian ini bertujuan untuk mengetahui pengaruh antar Pembinaan dan Disiplin baik secara parsial maupun secara simultan terhadap kinerja Guru Pada PAUD-PAUD di Kec. Talang Kelapa.Hipotesi yang diajukan (1). Diduga Pembinaan Secara Positif dan nyata berpengaruh terhadap kinerja Guru pada PAUD di Kec. Talang Kelapa.(2).Diduga Displin secara positif dan nyata berpengaruh terhadap Kinerja Guru PAUD di Kec. Talang Kelapa. (3) Motivasi secara positif dan Nyata berpengaruh terhadap kinerja Guru PAUD di Kec. Talang Kelapa. (4). Diduga Pembinaan Disiplin dan motivasi secara bersama-sama mempengaruhi kinerja Guru Pada PAUD di Kec. Talang Kelapa yang berjumlah 50 orang. Pengumpulan data yang digunakan adalah angket yang menggunakan skala Likert yang disusun berdasarkan kontruksi yang rangkum dari berbagai teori yang diwujudkan kedalam variable operasional, sedangkan pengujian terhadap instrument penelitian dilakukan melalui uji validitas dan uji reabilitas. Analisis data dilakukan melalui uji persyaratan yang terdiri dari uji normalitas yang menggunakan uji kolmogrof Smirnov, uji homogenitas dengan menggunakan uji Chi square, dan uji linearitas yang menggunakan OneWay Anova. Pengujian Hipotesis dilakukan dengan menggunakan analisis regresi dan korelasi antara variable Pembinaan dan Displin sebagai variable bebas terhadap Kinerja Guru sebagai variable terikat.Uji-T digunakan untuk mengetahui
\end{abstract}


pengaruh dari ketiga variabel bebas Pembinaan Disiplin dan Motivasi secara parcial terhadap Kinerja guru sebagai Variabel terikat. Sedangkan Uji-F untuk mengetahui pengaruh dari ketiga variabel bebas Pembinaan Displin dan Motivasi secara simultan terhadap Kinerja Guru sebagai variabel terikat. Taraf Signifikasi yang digunakan pada penelitiaan ini adalah $\alpha=5 \%$.Hasil Penelitian menunjukkan bahwa (1). Pembinaan, Disiplin dan Motivasi baik secara parsial dan secara simultan secara positif dan nyata berpengaruh terhadap Kinerja Guru pada PAUD di Kec. Talang Kelapa.

Kata Kunci : Kinerja Guru PAUD, Pembinaan, Disiplin, motivasi, Kecamatan Talang Kelapa

\section{PENDAHULUAN}

Pendidikan Anak Usia sejak Dini merupakan salah satu kunci mengatasi keterpurukan bangsa, khususnya dalam menyiapkan sumberdaya manusia yang handal nantinya. Berbagai penelitian bidang neurologi menunjukkan, bila anak distimulasi sejak dini, maka akan ditemukan genius (potensi paling baik/unggul) dalam dirinya. Setiap anak memiliki kemampuan tak terbatas dalam belajar yang telah ada dalam dirinya untuk dapat berpikir kreatif dan produktif. Oleh karena itu, anak memerlukan program pendidikan yang mampu membuka kapasitas tersembunyi tersebut melalui pembelajaran bermakna seawal mungkin. Bila potensi pada diri anak tidak pernah terealisasikan, maka itu berarti anak telah kehilangan peluang dan momentum penting dalam hidupnya, dan pada gilirannya negara akan kehilangan sumber daya manusia terbaiknya.
Perencanaan pembelajaran yang terarah sesuai dengan kurikulum PAUD harus dikuasai oleh guru PAUD. Dengan rendahnya pengetahuan dan keterampilan yang dimiliki guru PAUD di Kec. Talang Kelapa, maka sulit bagi guru PAUD untuk mengembangkan pembelajaran di PAUD, sehingga kegiatan pembelajaran tidak bervariasi, membosankan, dan dapat diterka.

Disamping permasalahan diatas, PAUD yang ada di

Kecamatan Talang Kelapa mengalami permasalahan dengan para tenaga pendidik atau guru, karena kinerja para guru PAUD sekarang belum juga menunjukkan hasil yang maksimal dimana masih ada guru yang sering tidak mengajar atau datang terlambat. Begitu juga dengan kesiapan mengajar guru, masih ada guru yang mengajarnya tidak menggunakan alat pembelajaran yang sesuai seperti pembuatan Rencana Kegiatan Harian 
(RKH) atau kesiapan mengajar seadanya saja.

Kinerja yang baik dari para guru PAUD diharapkan akan mampu meningkatkan hasil pembelajaran yang baik untuk masa yang akan datang, mengingat pada masa sekarang perhatian pemerintah pada Pendidikan Anak Usia Dini sangatlah besar sehingga PAUD juga mempunyai kewajiban untuk meningkatkan mutu pendidikan.

Pembinaan, kedisplinan, motivasi guru juga mempunyai peranan yang penting dalam kegiatan belajar mengajar. Dengan memiliki kedisplinan yang baik maka ada sikap, tingkah laku dan perbuatan baik, sehingga ada keseimbangan antara IQ, EQ, dan SQ.

Pembinaan guru sebagai upaya peningkatan tenaga pendidik memiliki tujuan agar guru terus berkembang sejalan dengan perkembangan ilmu pengetahuan dan teknologi. Pembinaan guru selalu menjadi prioritas, karena upaya ini didasari alasan bahwa indicator utama keberhasilan sekolah adalah kemampuan melaksanakan kegiatan belajar mengajar secara efektif dan efisien sesuai dengan tuntutan kurikulum dan menyiapkan lulusan yang mandiri dan siap memasuki jenjang pendidikan Sekolah Dasar.

Guru memiliki peranan yang strategis dan merupakan kunci keberhasilan mencapai tujuan kelembagaan sekolah, karena guru adalah pengelola KBM bagi peserta didiknya. Kegiatan belajar mengajar akan berjalan efektif apabila tersedia guru yang sesuai dengan kebutuhan sekolah baik jumlah, kualifikasi, maupun bidang ahlinya.

Kegiatan yang dapat dilakukan dalam rangka pembinaan guru dapat berupa sekolah lanjutan (S1 PAUD), pelatihan guru, workshop, seminar, PKG, diskusi dan sebagainya. Pembinaan mutu guru yang dilakukan tidak akan lepas dari Peningkatan kompetensi guru dan harus sesuai dengan system standarisasi guru di tiap-tiap jenis dan jenjang pendidikan sekolah. Tujuan dikembangkan standar kompetensi guru adalah untuk menetapkan suatu ukuran kemampuan pengetahuan dan ketrampilan yang harus dikuasai oleh seorang guru agar professional dalam merencanakan dan mengelola proses pembelajaran di sekolah (Suwondo, 
MS.2003) Selain aspek pengetahuan, ketrampilan, dan sikap professional, ada karakteristik psikolog individu yang berperan dalam meningkatkan produktivitas, yaitu displin. Guru yang memilki disiplin tinggi, senantiasa memiliki dorongan untuk bekerja gigih guna mencapai prestasi, hal ini disebabkan mereka memiliki kontrol kerja yang baik sehingga tidak memerlukan pengawasan yang ketat dalam mencapai kinerja yang telah ditentukan.

Kegiatan pembinaan yang diberikan kepada guru dan disiplin yang dimiliki guru mempunyai kaitan yang sangat erat dengan kinerja. Sehubungan dengan hal itu melalui pembinaan dan disilpin merupakan salah satu alternative yang tepat sebagai upaya meningkatkann produktifitas tenaga kerja.seiring dengan perkembangan teknologi dan ekonomi, peran manusia tidak hanya terbatas sebagai penyedia tenaga kerja yang bersumber dari kekuatan fisik, melaikan yang lebih penting adalah dapat menggunakan kemampuan cakrawala berpikir untuk merencankan dan melakukan kegiatan produktif

\section{A. IDENTIFIKASI MASALAH}

Sesuai dengan uraian dari latar belakang diatas dapat diidentifikasi beberapa masalah sebagai berikut :

1. Pembinaan guru PAUD secara kontinu belum maksimal

2. Masih rendahnya kedisiplinan guru PAUD Kec. Talang Kelapa

3. Masih sedikitnya guru PAUD yang memiliki jenjang pendidikan yang diharapkan.

4. Lingkungan kerja yang belum mendukung terciptanya iklim kerja yang baik.

5. Gaya kepemimpinan kepala sekolah yang diharapkan belum ideal

6. Kurangnya pelaksanaan supervisi

7. Rendahnya semangat dan kegairahan kerja

8. Honor yang diberikan sangat sedikit

9. Kurangnya pelatihan 


\section{B. Pembatasan Masalah}

Berdasarkan latar belakang identifikasi masalah yang diuraikan diatas,dan untuk lebih fokus pembahasan dalam penelitian ini disamping adanya keterbatasan waktu perlu dilakukan pembatasan masalah maka penulis hanya membatasi pada masalah Pengaruh Pembinan Disiplin dan Motivasi terhadap Kinerja Guru PAUD di Kec. Talang Kelapa.

\section{Perumusan Masalah}

Berdasarkan pembatasan masalah tersebut diatas, maka rumusan masalahnya adalah :

1. Apakah ada pengaruh Pembinaan terhadap Kinerja Guru PAUD Kec. Talang Kelapa ?

2. Apakah ada pengaruh Displin terhadap Kinerja Guru PAUD Kec. Talang Kelapa?

3. Apakah ada pengaruh Motivasi terhadap Kinerja Guru PAUD Kec. Talang Kelapa?

4. Apakah ada pengaruh Pembinaan Disiplin dan
Motivasi terhadap Kinerja

Guru PAUD di Kec. Talang

Kelapa ?

\section{Tujuan dan}

\section{Kegunaan Penelitian}

1. Tujuan Penelitian

Penelitian ini bertujuan untuk mengetahui :

a. Apakah ada pengaruh Pembinaan terhadap Kinerja Guru PAUD di Kec. Talang Kelapa

b. Apakah ada pengaruh Displin terhadap Kinerja Guru PAUD di Kec. Talang Kelapa

c. Apakah ada pengaruh Motivasi terhadap Kinerja Guru PAUD di Kec. Talang Kelapa

d. Apakah ada pengaruh Pembinaan Disiplin dan Motivasi terhadap Kinerja Guru PAUD di Kec. Talang Kelapa

2. Kegunaan Pendidikan

Dengan penelitian ini diharapkan hasil-hasil yang didapat akan memberikan kegunaan :

a. Membuktikan secara empiris Pembinaan Disiplin terhadap Kinerja Guru PAUD di Kec. Talang Kelapa 
b. Sebagai sumbangan bagi sekolah PAUD di Kec. Talang Kelapa untuk lebih memperhatikan Pembinaan dan Disiplin dan motivasi pada gurunya, dalam pengembangan Sumber Daya Manusia, sehingga kinerja guru benar-benar ditingkatkan, dan pedoman untuk menyusun rencana pembangunan dan pembinaan sumber daya manusia.

c. Secara teoritis

1). Diharapkan dapat memberikan konstribusi bagi ilmu pengetahuan bidang Manajemen Sumber Daya Manusia yang terkait dengan masalah Pembinaan Disiplin dan motivasi terhadap kinerja Guru PAUD Kec. Talang Kelapa.

2). Dapat dijadikan sebagai salah satu referensi bagi pihak yang ingin melakukan kajian lebih lanjut.

3). Sebagai salah satu input atau masukan bagi PAUD - PAUD yang ada di Kec. Talang Kelapa.

Kinerja dipandang sebagai hasil kerja seorang dalam suatu periode tertentu dibandingkan dengan berbagai kemungkinan, misalnya standart target/tujuan, atau kriteria yang telah ditentukan terlebih dahulu. Jadi kinerja guru merupakan hasil dari pekerjaan seorang guru dalam mendididkndan membina peserta dididk dalam kurun waktu tertentu. Kurun waktu tertentu dilaksanakan oleh guru dalam setiap tahunnya dalam dua semester, kinerja guru tersebut dapat dievaluasi melalui kemandirian peserta didik.

\section{KAJIAN TEORITIK}

\section{Teori Kinerja}

Kinerja berasal dari bahasa Inggris yang merupakan terjemahan bebas, yaitu "performance", yang berarti prestasi kerja atau pelaksanaan kerja atau pencapaian kerja atau hasil kerja/penampilan kerja (Suryadi,2008, h.1-2).

Buchori (1984, h.54) menyatakan bahwa prestasi kerja adalah hasil kerja yang dicapai seseorang pegawai dalam melaksanakan tugas yang dibebankan kepadanya sebaikbaiknya. Bagi seorang guru yang profesional tentunya akan terus memperbaiki cara mengajarkan. Dia tidak akan puas apabila hanya mengulang-ulang bahan pembelajaran yang telah disusunnya. 
Menurut Dharma (1992, h.25) Kinerja adalah sebagai alat untuk memberi informasi kepada pegawai atau pekerja dan atasannya bagaimana seseorang individu dapat melihat kemampuannya dan kesanggupan dalam suatu pekerjaan yang menjadi tanggung jawabnya.

Sedangkan Griffin (1987, h 389) menyatakan ada tiga hal yang menentukan kinerja seseorang, yaitu kemampuan, motivasi kerja, dan lingkungan

\section{Teori Pembinaan}

Pengertian pembinaan menurut Werther dan Davis (1996, h.282) adalah usaha untuk membantu individu menangani tanggung jawab masa depan yang berorientasi pada pelaksanaan tugas, pembinaan individu mencurahkan perhatiannya pada individu sebagai pribadi, dalam hubungannya dengan pekerjaan dan organisasi, dan menaruh perhatian terutama pada hubungan perorangan. Selanjutnya menurut Gilley dan Eggland (1989 h.4-5) juga menyatakan pembinaan adalah upaya mengarahkan individu untuk mengikuti perkembangan ilmu pengetahuan dan teknologi serta imam dan taqwa, meningkatkan ketrampilan, kompetensi, serta memperbaiku perilaku individu dalam organisasi baik pribadi maupun profesi.

\section{Teori Disiplin}

Menurut Nitisemito (1982, h.213) disiplin dapat diartikan sebagai suatu sikap, tingkah laku yang menunjukkan ketaatan karyawan terhadap peraturan organisasi. Menurut Hodges dalam (Yuspratiwi (1990 h.11) disiplin dapat diartikan sebagai sikap seseorang atau kelompok yang berniat untuk mengikuti aturan-aturan yang telah ditetapkan. Senada Menurut Moenir (2006, h.94) mengemukakan disiplin adalah suatu bentuk ketaatan terhadap aturan, baik tertulis maupun tidak tertulis yang telah ditetapkan.

\section{Teori Motivasi}

Motivasi dapat diartikan sebagai kekuatan (energi) seseorang yang dapat menimbulkan tingkat persistensi dan antuasiasmenya dalam melaksanakan kegiatan baik bersumber dari dalam diri individu itu sendiri maupun dari luar (motivation) kata dasarnya adalah 
motif (motive) yang berarti dorongan, sebab atau alasan seseorang melakukan sesuatu. Hasibuan, malayu (2012 : 219) menyimpulkan bahwa motivasi adalah "pemberian daya penggerak yang menciptkan kegairahan kerja seseorang, agar mereka mau bekerjasama, bekerja efektif dan terintegrasi dengan segala daya

upayanya untuk mencapai kepuasan.".

\section{METODOLOGI PENELITIAN A.}

\section{Waktu dan Tempat Penelitian}

a. Waktu Penelitian

Penelitian dilaksanakan selama 5 lima bulan sejak proses perencanaan, pelaksanaak dan pelaporan hasil penelitian.

b. Tempat penelitian

Tempat untuk melaksanakan penelitian pada PAUD-PAUD di Kec. Talang Kelapa

\section{B. Populasi dan Teknik Pengambilan Sampel}

1. Populasi

Populasi menurut Sugiono (2002) seperti yang dikutip Haryono (2007, h.91) adalah wilayah generalisasi yang terdiri atas objek atau subjek yang mempunyai kuantitas dan karakteristik tertentu yang diharapkan oleh peneliti untuk dipelajari dan dikemudian ditarik kesimpulannya. Berdasarkan data UPTD Diknas Kecamatan Talang Kelapa PAUD yang berjumlah 25 PAUD. Populasi dalam penelitian ini adalah seluruh guru PAUD di Kec. Talang Kelapa.

2. Teknik Pengambilan Sampel Sampel menurut Haryono (2008, h.21) adalah satu set atau kumpulan data penelitian yang merupakan bagian dari populasi

\section{Desain Penelitian}

Penelitian ini akan dilaksanakan dengan metode survey dengan pendekatan korelasional yang melibatkan 4 variabel; 3 variabel terikat 1 variabel bebas. Teknik korelasional digunakan untuk mengukur kualitas hubungan antara pembinaan guru, disiplin dan motivasi guru, dengan kinerja guru baik sendiri-sendiri; maupun bersama-sama.

\section{Uji Validitas}

Sebelum kuisioner digunakan untuk mengumpulkan data, terlebih dahulu diuji validitasnya, dengan 
menggunakan rumus teknik korelasi item total Product moment terhadap 30 orang guru yang dijadikan sampel untuk uji coba instrument.

\section{Uji Reliabilitas}

Pengujian realiabilitas dilakukan setelah melihat tingkat validitas instrument yang dilakukan terhadap 30 orang responden dengan mengambil instrument yang valid sedangkan yang drop tidak digunakan dalam penelitian.

\section{Teknik Analisa Data}

\section{Uji Persyaratan Analisa Data}

\section{Uji Normalitas}

Uji normalitas dipergunakan untuk melihat apakah sebaran data hasil penelitian terdistribusi normal atau tidak. Pengujian dilakukan terhadap semua item pernyataan yang sudah dinyatakan valid atau reliabel. Data yang berdistribusi normal dalam suatu model regresi dapat dilihat pada grafik normal $\mathrm{p}-\mathrm{p}$ plot, dimana bila titik-titik menyebar disekitar garis diagonal serta penyebarannya mengikuti arah garis homogenitasnya. Uji homogenitas

ini perlu untuk memastikan apakah data penelitian ini dilakukan dengan diagonal, maka data tersebut

dikatakan berdistribusi normal.

Untuk melakukan uji normalitas

distribusi data, penulis menggunakan uji Kolmogrof-Smirnov dari program SPSS. Normalitas distribusi data dihitung dengan cara membandingkan nilai Asymtotic Significance yang diperoleh dengan nilai $\alpha=0,05$. Apabila Asymp. Sig $>\alpha=0,05$, maka data dinyatakan normal.

\section{Uji Homogenitas}

Sebagai salah satu persyaratan untuk melakukan analisis data terhadap jumlah responden sebanyak 30 orang dengan menggunakan analisis regresi, data perlu diuji

homogenitasnya. Pengujian homogenitas pada penelitian ini dilakukan dengan menggunakan Uji Chi-sguare dengan menetapkan Sigifikansi $5 \quad \% \quad(\alpha=0,05)$. Interpretasi homogenitas data dihitung berdasarkan nilai Asymtotic Significance yang diperoleh jika Asymp. Sig $>\alpha=0,05$.

\section{Uji Liniearitas}

menggunakan Uji Chi-Square dengan menetapkan signifikansi $5 \%(\alpha=0,05)$. Interprestasi homogenitas data 
dihitung berdasarkan nilai Asymtotic

Significance yang diperoleh. Jika Asymp. Sig. $>\alpha=0,05$, maka data dinyatakan homogennya.

Uji liniearitas dipergunakan untuk mengetahui apakah regresi yang diperoleh "berarti" apabila jumlah responden sebanyak 30 orang dipergunakan untuk membuat kesimpulan antara variabel yang sedang dianalisis. Pengujian liniearitas variabel bebas dengan variabel terikat dilakukan. Dengan menggunakan Oneway Anova Program SPSS. Pengujian liniearitas menggunakan taraf signifikansi $5 \%(\alpha=0,05)$. Interprestasi data dilakukan dengan ketentuan jika Sign. $\mathrm{F}$-hitung $<\mathrm{F}-$ table, maka variabel bebas dengan variabel terikat tersebut mempunyai hubungan yangliniear.

\section{HASIL DAN PEMBAHASAN}

\section{A. Uji Normalitas}

Tabel 19. Uji Normalitas

\section{One-Sample Kolmogorov-Smirnov Test}

\begin{tabular}{|c|c|c|c|c|}
\hline & Kinerja (Y) & Pembinaan (X1) & Disiplin (X2) & Motivasi (X3) \\
\hline $\mathrm{N}$ & 30 & $3 p$ & $3 p$ & 31 \\
\hline Norm Mean & 104.97 & 92.97 & 86.30 & 96.47 \\
\hline $\begin{array}{l}\text { al } \\
\text { Param } \\
\text { eters } \\
b \text {, }\end{array}$ & 10.135 & 11.162 & 6.660 & 7.171 \\
\hline Most Absolute & .141 & .174 & .099 & .196 \\
\hline Extre Positive & .084 & .140 & .099 & .071 \\
\hline $\begin{array}{l}\text { me } \\
\text { Differ Negative } \\
\text { ences }\end{array}$ & -.141 & -.174 & -.093 & -.196 \\
\hline Kolmogorov-Smirnov Z & .770 & .953 & .544 & 1.075 \\
\hline Asymp. Sig. (2-tailed) & .593 & .324 & .929 & .198 \\
\hline
\end{tabular}

Nilai Asymp. Sign. untuk ketiga variabel $\left(\mathrm{Y}, \mathrm{X}_{1}, \mathrm{X}_{2}\right)$ diperoleh masing - masing Y sebesar 0,593

\section{; X1 0,324, X2 0,929 dan X3}

0,198 diatas nilai $\alpha=0,05$ maka 
disimpulkan bahwa data populasi

berdistribusi normal. (ChiSquare)

\section{b. Uji Homogenitas}

Sebagai salah satu persyaratan untuk melakukan analisis data terhadap responden sebanyak 30 orang dengan menggunakan analisis regresi, data perlu diuji homogenitasnya. Uji homogenitas ini perlu

untuk memastikan apakah data tersebut berasal dari populasi yang homogen. Pengujian homogenitas pada penelitian ini dilakukan dengan menggunakan Uji Chisquare dengan menetapkan

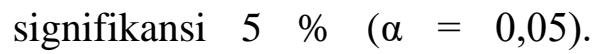
Interpetasi homogenitas data dihitung berdasarkan nilai Asymtotic Significance yang diperoleh. Jika Asymp. Sig. $>\alpha=$ 0,05, maka data dinyatakan homogen, seperti pada tabel berikut

\section{Hasil Uji homogenistas (Chisquare) \\ Test Statistics}

\begin{tabular}{|l|r|r|r|r|}
\hline & Kinerja (Y) & Pembinaan (X1) & Disiplin (X2) & \multicolumn{1}{c|}{ Motivasi (X3) } \\
\hline Chi-Square & 11.933 & $7.200^{\mathrm{b}}$ & $8.400^{\mathrm{b}}$ & $12.000^{\mathrm{b}}$ \\
Df & 16 & 17 & 17 & 17 \\
Asymp. Sig. & .749 & .981 & .957 & .800 \\
\hline
\end{tabular}

Interprestasi Output : Karena nilai Asymp. Sign. untuk ketiga variabel (Y, $\mathrm{X}_{1}, \mathrm{X}_{2}$ ) diperoleh masing - masing sebesar 0,$749 ; 0,981 ; 0,957$ dan 0,800

\section{c. Uji Linearitas}

Uji linearitas dipergunakan untuk mengetahui apakah regresi yang diperoleh "berarti" apabila jumlah responden sebanyak 30 orang dipergunakan untuk diatas nilai $\alpha=0,05$ maka disimpulkan bahwa data populasi memiliki varians homogen. membuat kesimpulan antar variabel yang sedang dianalisis. Pengujian linearitas variabel bebas dengan variabel terikat dilakukan dengan menggunakan One-way 
Anova program SPSS. Pengujian linearitas menggunakan taraf siginikansi $5 \quad \% \quad(\alpha=0.05)$. Interpretasi data dilakukan dengan ketentuan jika Sign. F-hitung < 0,05, maka variabel bebas dengan variabel terikat tersebut mempunyai hubungan yang linear.

Tabel 21. Hasil Uji Linearitas untuk Variabel X1 terhadap Y ANOVA Table

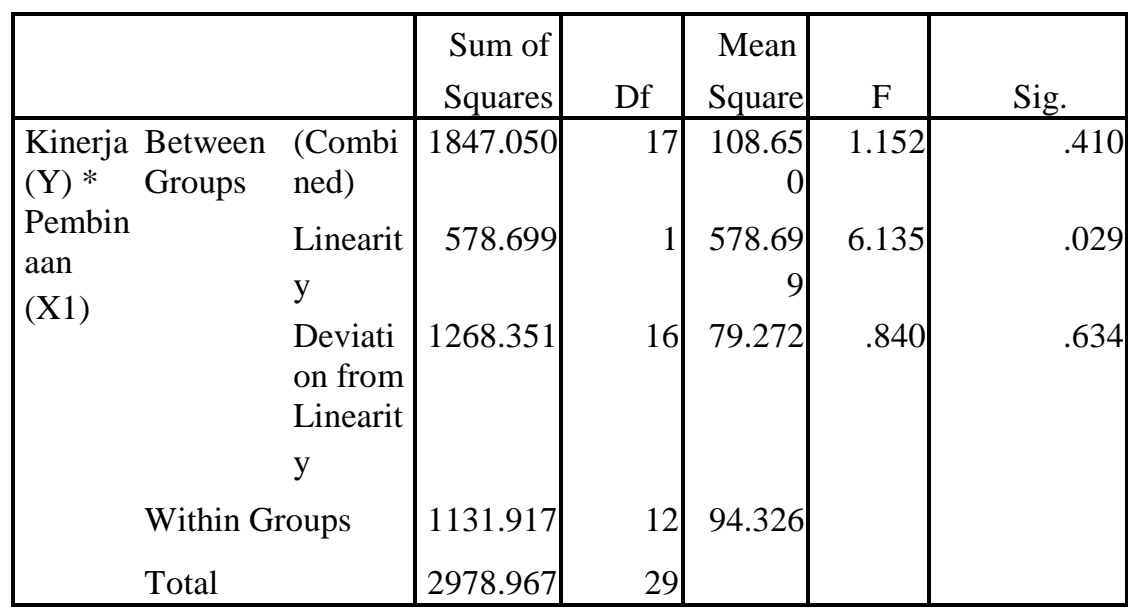

Tabel 22. Hasil Uji Linearitas untuk Variabel X2 terhadap Y ANOVA Table

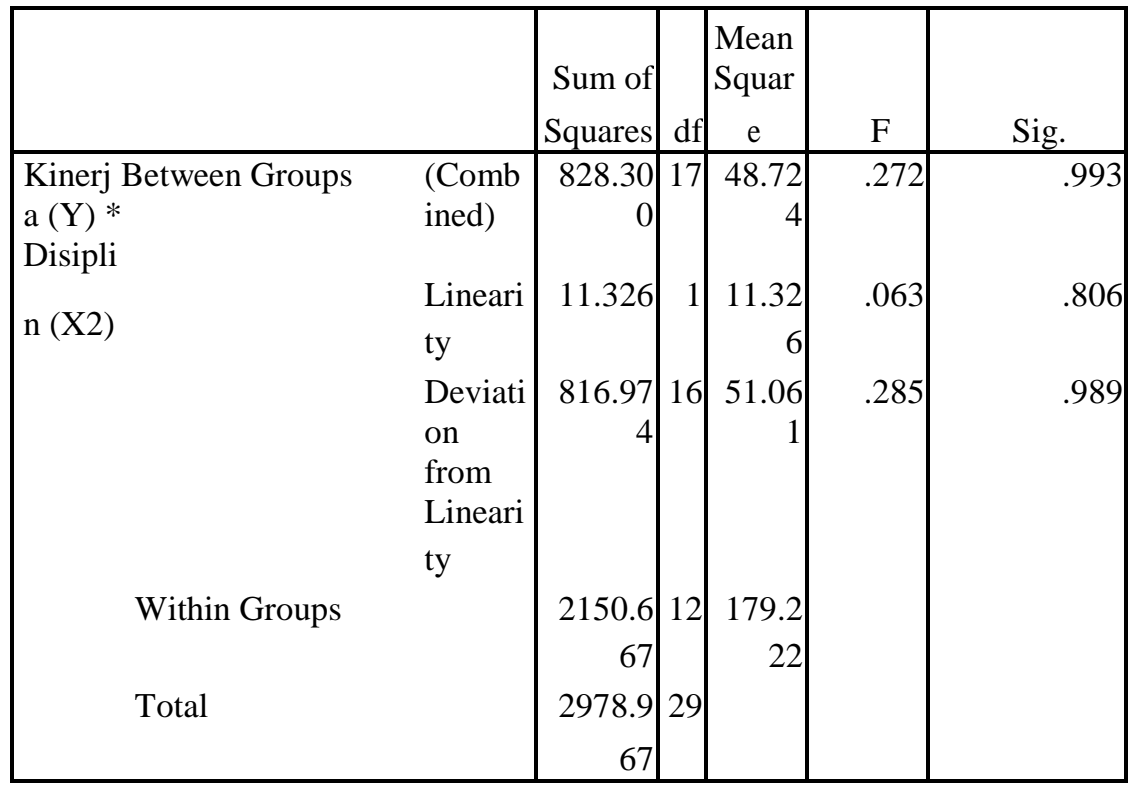


Tabel 23. Hasil Uji Linearitas untuk Variabel $\mathrm{X}_{3}$ terhadap Y

\begin{tabular}{|c|c|c|c|c|c|c|}
\hline & & $\begin{array}{c}\text { Sum of } \\
\text { Squares }\end{array}$ & Df & $\begin{array}{l}\text { Mean } \\
\text { Square }\end{array}$ & $\mathrm{F}$ & Sig. \\
\hline Kinerj Between & (Combin & 1829.4 & 17 & 107.614 & 1.123 & .428 \\
\hline si (X3) & Linearity & 471.36 & 1 & 471.366 & 4.921 & .047 \\
\hline & $\begin{array}{l}\text { Deviation } \\
\text { from }\end{array}$ & $\begin{array}{r}1358.0 \\
68\end{array}$ & 16 & 84.879 & .886 & .597 \\
\hline & Linearity & & & & & \\
\hline Within C & oups & 1149.5 & 12 & 95.794 & & \\
\hline Total & & 2978.9 & 29 & & & \\
\hline
\end{tabular}

Interpetasi dari tabel diatas : Nilai

Sign. pada baris Deviation from

Linearity pada kedua tabel ANOVA diatas diperoleh masing - masing sebesar $0,634, \quad 0,989$ dan 0,597 keduanya lebih besar dari $\alpha$ sebesar $5 \%$, maka $\mathrm{H}_{\mathrm{o}}$ diterima artinya variabel $\mathrm{Y}$ dengan variabel $\mathrm{X}_{1}$ mempunyai hubungan yang linier dan variabel $\mathrm{Y}$ dengan variabel $\mathrm{X}_{2}$ juga mempunyai hubungan yang linier.

\section{Analisis Statistik Inferensial Setelah}

dilakukan analisis statistik

deskriptif melalui pengujian persyaratan analitis, kemudian

dilanjutkan analisis statistik inferensial dengan menggunakan teknik analisis korelasi, analisis regresi linier, koefisien determinasi dan analisis varians (Anova).

\section{Analisis Regresi Berganda}

Analisis regresi Berganda digunakan untuk mengetahui besarnya pengaruh yang terjadi pada variabel Pembinaan (X1) Disiplin (X2), dan Motivasi (X3) terhadap Kinerja secara simultan. Setelah dilakukan pengolahan data maka didapat tabel Regresi berganda sebagai berikut : 
Tabel 24

Hasil Analisis Regresi Linear Berganda

\begin{tabular}{|c|c|c|c|c|c|}
\hline \multicolumn{6}{|c|}{ Coefficients $^{\mathrm{a}}$} \\
\hline \multirow[b]{2}{*}{ Model } & \multicolumn{2}{|c|}{ Unstandardized Coefficients } & \multirow{2}{*}{\begin{tabular}{|c|}
$\begin{array}{c}\text { Standar } \\
\text { dized } \\
\text { Coeffic } \\
\text { ients }\end{array}$ \\
Beta \\
\end{tabular}} & \multirow[b]{2}{*}{$\mathrm{T}$} & \multirow[b]{2}{*}{ Sig. } \\
\hline & $\mathrm{B}$ & Std. Error & & & \\
\hline 1 (Constant) & 6.655 & 39.581 & & .168 & .868 \\
\hline Pembinaan (X1) & .365 & .147 & .402 & 2.485 & .020 \\
\hline Disiplin (X2) & .135 & .262 & .089 & .517 & .610 \\
\hline Motivasi (X3) & .546 & .245 & .386 & 2.231 & .035 \\
\hline
\end{tabular}

a. Dependent Variable : Kinerja (Y)

Analisis output diatas adalah menunjukkan bahwa koefisien regresi untuk variable Pembinaan (X1) 0,365 Disiplin (X2) 0,135, dan Motivasi (X3) 0,546 yang juga menghasilkan nilai konstanta sebesar 6,665 sehingga persamaan regresi berganda penelitian ini adalah sebagai berikut : $\mathrm{Y}=6,665$ $+0,365 \mathrm{X}_{1}+0,135 \mathrm{X}_{2}+0,546 \mathrm{X}_{3}+\mathrm{e}$. Hasil perhitungan dapat di interpretasikan sebagai berikut :

- Konstantasebesar 6,665 menyetakan bahwa tidak ada peningkatan Disiplin (X2) Pembinaan (X1) (secara matematika, X1, X2 dan X3 adalah 0, maka Kinerja tetap sebesar 6,665 unit skor. Hal ini bisa dipahami karena masih banyak variabel lain yang belum dimasukkan dalam penelitian ini, seperti Insentif Guru, Tunjangan Sertifikasi, Tingkat Pendidikan, Tingkat Pengalaman dan Masa Kerja Guru. Dll.

- Dengan melihat besarnya koefisien regresi bahwa Pembinaan (X1) 0,365 atau sama dengan $36,5 \%$ artinya kecenderungan proyeksi perubahan antara bariabel Pembinaan (X1) dengan variabel Kinerja (Y) menunjukkan bahwa setiap perubahan atau peningkatan variabel Pembinaan (X1) sebesar $100 \%$ maka mengakibatkan perubahan atau peningkatan pula pada variabel Kinerja sebesar $36,5 \%$ dengan tingkat signifikansi $5 \%$.

- Dengan melihat besarnya koefisien regresi bahwa Disiplin 
(X2) 0,135 atau sama dengan

$13,5 \%$ artinya kecenderungan perubahan antara bariabel Disiplin (X2) dengan variabel Kinerja (Y) menunjukkan bahwa setiap perubahan atau peningkatan variabel Disiplin (X2)

- sebesar $100 \%$ maka mengakibatkan perubahan atau peningkatan pula pada variabel Kinerja sebesar 13,5\% dengan tingkat signifikansi 5\%.

- Dengan melihat besarnya koefisien regresi bahwa Motivasi (X3) 0,546 atau sama dengan $54,6 \%$ artinya kecenderungan perubahan antara variabel Disiplin (X2) dengan variabel Kinerja (Y) menunjukkan bahwa setiap perubahan atau peningkatan variabel Disiplin (X2) sebesa $100 \%$ maka mengakibatkan perubahan atau peningkatan pula pada variabel Kinerja sebesar 54,6 $\%$ dengan tingkat signifikansi $5 \%$.
Ketiga variabel bebas tersebut variabel Pembinaan (X1), Disiplin (X2) dan Motivasi (X3) berkorelasi positif dengan Kinerja artinya bila variabel Pembinaan (X1), Disiplin (X2) dan Motivasi (X3) meningkat maka akan mengakibatkan meningkatkan Kinerja, begitu pula sebaliknya, apabila variabel Pembinaan (X1) Disiplin (X2) dan Motivasi (X3) menurun Kinerja juga akan menurun

\section{Analisis Korelasi dan Koefisien Determinasi}

\section{a. Analisis Korelasi}

Dengan memperhatikan tabel 25 berikut kita dapat melihat pengaruh dari ketiga variabel yang kita inginkan : 
Tabel 25

Korelasi Antar Variabel

Correlations

\begin{tabular}{|c|c|c|c|c|}
\hline & Kinerja $(\mathrm{Y})$ & $\begin{array}{c}\text { Pembinaan } \\
(\mathrm{X} 1)\end{array}$ & Disiplin (X2) & Motivasi (X3) \\
\hline Kin Pearson Correlation & 1 & $.441^{*}$ & .062 & $.398^{\circ}$ \\
\hline erja Sig. (2-tailed) & & .015 & .746 & .029 \\
\hline${ }^{(\mathrm{Y})} \mathrm{N}$ & 30 & 30 & 30 & 30 \\
\hline Pe Pearson Correlation & $.441^{*}$ & 1 & .035 & .107 \\
\hline $\begin{array}{l}\text { mb Sig. (2-tailed) } \\
\text { ina }\end{array}$ & .015 & & .856 & .573 \\
\hline $\begin{array}{l}\text { an } \mathrm{N} \\
(\mathrm{X}\end{array}$ & 30 & 30 & 30 & 30 \\
\hline 1) & & & & \\
\hline Dis Pearson Correlation & .062 & .035 & 1 & .354 \\
\hline ipli Sig. (2-tailed) & .746 & .856 & & .055 \\
\hline $\begin{array}{l}(X \mathrm{X} \\
2)\end{array}$ & 30 & 30 & 30 & 30 \\
\hline Mo Pearson Correlation & $.398^{*}$ & .107 & .354 & 1 \\
\hline tiva Sig. (2-tailed) & .029 & .573 & .055 & \\
\hline$(\mathrm{X} \quad \mathrm{N}$ & 30 & 30 & 30 & 30 \\
\hline 3) & & & & \\
\hline
\end{tabular}

*. Correlation is significant at the 0.05 level (2-tailed).

Interpretasi dari tabel diatas

adalah :

- Sedangkan korelasi antara

Pembinaan (X1) dengan

Kinerja (Y) adalah sebesar

0,4641. Artinya pengaruh

antara Pembinaan (X1)

dengan Kinerja (Y) kuat dan

bersifat positif (searah). Jika

skor Pembinaan (X1) naik

maka skor Kinerja Kinerja

juga akan meningkat, begitu

juga sebaliknya.
- Korelasi antara Disiplin (X2) dengan Kinerja (Y) adalah sebesar 0,062. Artinya pengaruh antara Disiplin (X2) dengan Kinerja (Y) sagat lemah. Jika skor Disiplin (X2)

- naik maka skor Kinerja Kinerja juga akan meningkat, begitu juga sebaliknya.

- Sedangkan korelasi antara Pembinaan (X1) dengan Kinerja (Y) adalah sebesar 0,398. Artinya pengaruh 
antara Pembinaan (X1)

dengan Kinerja (Y) kuat dan

bersifat positif (searah). Jika

skor Pembinaan (X1) naik maka skor Kinerja Kinerja juga akan meningkat, begitu juga sebaliknya.

\section{Koefisien Determinasi}

\begin{tabular}{lrrrrr}
\multicolumn{2}{c}{ Koefisien } & determinasi & & variabel independen (X1 X2 dan \\
gunanya & untuk & mengukur & & X3) dalam model regresi. Hasil \\
seberapa & bagian & dari & total & & perhitungan nilai koefisien \\
keragaman & dalam & variabel & & dterminasi ditunjukkan pada tabel \\
dependen & (Y) yang & dapat & & berikut :
\end{tabular}

dijelaskan oleh beragamnya nilai-

nilai yang diberikan setiap

Tabel 26

Analisis Korelasi dan Koefisien Determinasi Variabel X1 dengan Y

\begin{tabular}{|c|c|c|c|c|}
\hline \multicolumn{5}{|c|}{ Model Summary } \\
\hline \begin{tabular}{|l}
$\mathrm{M}$ \\
$\mathrm{o}$ \\
$\mathrm{d}$ \\
$\mathrm{e}$ \\
$\mathrm{l}$
\end{tabular} & $\mathrm{R}$ & $\begin{array}{l}\mathrm{R} \\
\mathrm{S} \\
\mathrm{qu} \\
\mathrm{ar} \\
\mathrm{e}\end{array}$ & $\begin{array}{c}\text { Adjuste } \\
\text { d R } \\
\text { Square }\end{array}$ & $\begin{array}{l}\text { Std. Error of the } \\
\text { Estimate }\end{array}$ \\
\hline 1 & $\begin{array}{l} \\
5 \\
7 \\
1 \\
\text { a }\end{array}$ & $\begin{array}{l}.3 \\
26\end{array}$ & .248 & 8.791 \\
\hline
\end{tabular}

a. Predictors: (Constant), Motivasi (X3), Pembinaan (X1), Disiplin (X2)

Dari tabel tersebut

didapat koefisien korelasi 571 dan Koefien

Determinasi $\left(\mathrm{R}^{2}\right)$ Adjusted Square adalah 0,326. Hal ini berarti $32,6 \%$ variasi nilai skor variabel Kinerja Kinerja bisa dijelaskan secara bersama - sama oleh

\section{Pembinaan (X1) Disiplin}

(X2) dan Motivasi (X3).

Sisanya $67,4 \%$ dijelaskan oleh faktor lain (e). 
D. Pengujian Hipótesis Statistik

1. Pengaruh Pembinaan, Disiplin dan Motivasi secara bersama-sama terhadap Kinerja Guru PAUD Kec. Talang Kelapa

$\mathrm{H}_{0}: \mathrm{b}_{1}: \mathrm{b}_{2}=0$, tidak ada pengaruh Pembinaan, Disiplin dan Motivasi secara bersama-sama terhadap Kinerja
Guru PAUD

Kec. Talang Kelapa

$\mathrm{H}_{0}: \mathrm{b}_{1}: \mathrm{b}_{2}>0$, ada pengaruh Motivasi dan Disiplin secara bersama-sama terhadap Kinerja Guru PAUD Kec. Talang Kelapa

Kriteria pengujian :

Ho diterima, jika sig. $F \geq 0,05$

Ho ditolak, jika sig. $F<0,05$

Tabel. 27

Pengujian Hipotesis Menggunakan Uji F

\begin{tabular}{|l|r|r|r|c|c|}
\hline Model & Sum of Squares & Df & Mean Square & F & \multicolumn{1}{c|}{ Sig. } \\
\hline 1 Regression & 969.756 & 3 & 323.252 & 4.183 & $.015^{\mathrm{a}}$ \\
Residual & 2009.211 & 26 & 77.277 & & \\
Total & 2978.967 & 29 & & & \\
\hline
\end{tabular}

a. Predictors: (Constant), Motivasi (X3), Pembinaan (X1), Disiplin (X2)

b. Dependent Variable: Kinerja (Y)

Kesimpulan : Terdapat pengaruh positif Pembinaan (X1), Disiplin (X2) dan Motivasi (X3) secara bersama-sama terhadap Kinerja Guru PAUD Kec. Talang Kelapa (Y). Hal ini dapat dilihat dari nilai uji $\mathrm{F}$ dimana nilai F-hitung sebesar 0,000 lebih kecil dari tingkat signifikansi 5\% $(\alpha=0,05)$.

$$
\text { 2. Pengaruh Pembinaan }
$$

Kec. Talang Kelapa

$$
\begin{array}{ll}
\mathrm{H}_{0}: \mathrm{b}_{1}=0, & \text { tidak ada } \\
& \text { pengaruh } \\
& \text { Pembinaan } \\
& \text { terhadap } \\
& \text { Kinerja Guru } \\
& \text { PAUD Kec. } \\
& \text { Talang Kelapa } \\
& \text { ada pengaruh } \\
& \text { Pembinaan } \\
\mathrm{H}_{0}: \mathrm{b}_{1}>0, & \text { terhadap } \\
& \text { Kinerja Guru }
\end{array}
$$


PAUD Kec.

Talang Kelapa

Kriteria pengujian :

Ho diterima, jika sig.t $\geq 0,05$

Ho ditolak, jika sig.t $<0,05$

Berdasarkan tabel 25

pengujian hipotesis maka

secara statistik: Terdapat

pengaruh positif Pembinaan

(X1) terhadap Kinerja Guru

PAUD Kec. Talang Kelapa

(Y). Hal ini dapat dilihat dari

nilai uji t dimana nilai sig sebesar 0,020 lebih kecil dari $5 \%(\alpha=0,05)$.

3. Pengaruh Disiplin terhadap Kinerja Guru PAUD Kec. Talang

\section{Kelapa}

$\mathrm{H}_{0}: \mathrm{b}_{2}=0, \quad$ tidak

pengaruh

Disiplin terhadap

Kinerja Guru

PAUD Kec.

Talang Kelapa

$\mathrm{H}_{0}: \mathrm{b}_{2}>0$, ada pengaruh

positif Disiplin

terhadap Kinerja

Guru PAUD
Kec. Talang

Kelapa

Berdasarkan tabel 25

pengujian hipotesis maka secara statistik : Tidak terdapat pengaruh positif Disiplin (X2) dengan Kinerja Guru PAUD Kec. Talang Kelapa (Y). Hal ini dapat dilihat dari nilai uji $\mathrm{t}$ dimana nilai sig sebesar 0,610 lebih besar dari 5\% $(\alpha=0,05)$

4. Pengaruh Motivasi terhadap Kinerja Guru PAUD Kec. Talang

\section{Kelapa}

$$
\begin{aligned}
& \mathrm{H}_{0}: \mathrm{b} 2=0, \quad \text { tidak } \quad \text { ada } \\
& \text { pengaruh } \\
& \text { Motivasi terhadap } \\
& \text { Kinerja Guru } \\
& \text { PAUD Kec. } \\
& \text { Talang Kelapa } \\
& \mathrm{H}_{0}: \mathrm{b}_{2}>0, \text { ada pengaruh } \\
& \text { positif Motivasi } \\
& \text { terhadap Kinerja } \\
& \text { Guru PAUD Kec. } \\
& \text { Talang Kelapa } \\
& \text { Dilihat dari tabel } 25
\end{aligned}
$$


dimana nilai sig sebesar 0,035

lebih kecil dari $5 \%(\alpha=0,05)$

\section{E. Interpretasi Hasil Penelitian}

Hasil analisis regresi berganda pengaruh variabel pembinaan, disiplin dan motivasi terhadap kinerja guru PAUD Kec. Talang Kelapa memberikan petunjuk, bahwa model persamaan $Y=6,665+0,365 X_{1}+0,135 X_{2}+$ $0,546 \mathrm{X}_{3}+\mathrm{e}$ dengan koefisien korelasi (r) secara simultan sebesar 0,571 dan koefisien Adjusted determinasi $\quad\left(\mathrm{R}^{2}\right) \quad$ sebasar 0,326didukung oleh tingkat signifikansi sebesar $5 \%$.

Temuan ini menunjukkan bahwa terdapat pengaruh variabel pembinaan, disiplin dan motivasi terhadap kinerja guru PAUD Kec. Talang Kelapa secara bersamasama , dimana 2732,6 \% variasi yang terjadi pada kinerja guru PAUD Kec. Talang Kelapa dapat dijelaskan oleh variabel Pembinaan, disiplin kerja dan Motivasi. Artinya, kinerja memiliki arah pengaruh positif dari ketiga variabel pembinaan, disiplin dan motivasi. Dengan demikian bila terjadi perubahan kearah positif dari ketiga variabel bebas tersebut akan memberikan pengaruh yang positif pula pada kinerja guru PAUD Kec. Talang Kelapa begitu pula sebaliknya.

\section{KESIMPULAN, IMPLIKASI}

DAN SARAN

\section{A. Kesimpulan}

Sesuai analisis data dan pengujian hipotesis yang telah dipaparkan pada bab - bab terdahulu, maka dapat ditarik beberapa kesimpulan yaitu sebagai berikut

1. Terdapat pengaruh positif Pembinaan (X1), Disiplin (X2) dan Motivasi (X3) secarabersama-sama terhadap Kinerja Guru PAUD Kec. Talang Kelapa (Y). Hal ini dapat dilihat dari nilai uji $\mathrm{F}$ dimana nilai F-hitung sebesar 0,000 lebih kecil dari tingkat signifikansi $5 \%(\alpha=0,05)$.

2. Terdapat pengaruh positif Pembinaan (X1) terhadap Kinerja Guru PAUD Kec. Talang Kelapa (Y). Hal ini dapat dilihat dari nilai uji $\mathrm{t}$ 
dimana nilai sig sebesar 0,020 lebih kecil dari 5\% $(\alpha=0,05)$

3. Tidak terdapat pengaruh positif Disiplin (X2) dengan Kinerja Guru PAUD Kec. Talang Kelapa

(Y). Hal ini dapat dilihat dari nilai uji t dimana nilai sig sebesar 0,610 lebih besar dari $5 \%(\alpha=0,05)$

4. Terdapat pengaruh positif Motivasi (X3) dengan Kinerja Guru PAUD Kec. Talang Kelapa (Y). Hal ini dapat dilihat dari nilai uji t dimana nilai sig sebesar 0,035 lebih kecil dari $5 \%(\alpha=0,05)$

\section{B. Implikasi}

Berdasarkan hasil penelitian diatas diketahui bahwa ketiga hipotesis penelitian yang diajukan diterima, yaitu :

1. Pembinaan yang terjadi di PAUD Kec. Talang Kelapa sepenuhnya merupakan hal yang perlu

ditingkatan dan bahkan pembenahan, walaupun terdapat pengaruh yang positif dan nyata serta kuat.

2. Motivasi di PAUD Kec. Talang Kelapa, pada prinsipnya sudah baik tetapi masih perlu ditingkatkan sekalipun terdapat pengaruh yang positif, nyata dan kuat.

3. Pembinaan dan Motivasi merupakan pendukung kinerja guru di PAUD Kec. Talang Kelapa dimana ini merupakan suatu usaha perbaikan kinerja, motivais dan disiplin secara menyeluruh, namun demikian tetap perlu adanya perbaikan dan peningkatan.

\section{Saran}

Hal ini menunjukkan bahwa upaya untuk meningkatkan kinerja dapat dilakukan melalui upaya peningkatan Pembinaan dan Motivasi. Berikut ini dikemukakan beberapa upaya meningkatkan motivasi dan disiplin kerja yang pada gilirannya akan meningkatkan kinerja .

\section{Upaya Meningkatkan}

\section{Pembinaan}

Upaya meningkatkan

Pembinaan dalam rangka memberi kontribusi terhadap kinerja guru PAUD Kec. Talang Kelapa dengan cara memberikan kesempatan kepada guru untuk mengikuti pendidikan tinggi untuk meningkatkan karir guru. 


\section{Upaya Meningkatkan Motivasi}

Upaya meningkatkan Motivasi dalam rangka memberikan kontribusi terhadap kinerja guru PAUD Kec. Talang Kelapa dengan cara memberikan pujian terhadap keberhasilan guru dalam melakukan pekerjaan dan memberikan bimbingan atau arahan kepada guru untuk menyelesaikan tugas dengan baik.

\section{DAFTAR PUSTAKA}

Buchori, Alma, 1984. Studi Tentang Produktivitas Tenaga Edukatif, FPS IKIP Bandung

Dharma, Agus, 1991, Manajemen Prstasi Kerja, Rajawali Press, Jakarta

Griffin, 1987, Supervision in Thought and Action, New York, Macmillan Publishing

Gilley, Jery W., dan Steven A. Eggland, 1989, Principles of Human Resources Development, AddisonWesley Publishing Company Inc., Califonia.

Haryono, Siswoyo, 2007, Metedologi Penelitian Bisnis, MM UTP, Palembang

Haryono, Siswoyo, 2008, Sukses Menulis Tesis : untuk Bisnis dan Manajemen, MM UTP, Palembang.

Moenir, A.S., 2006, Manajemen Pelayanan Umum di Indonesia, PT. Bumi Aksara, Jakarta
Nitisemito, Alex S., 1982, Manajemen Personalia : Manajemen Sumber Daya manudia, Ghalia Indonesia : Jakarta

Suryadi, 2008, Kebijakan Kinerja Karyawan, BFFE, Yogyakarta

Suwondo, Edi S., 2003, Guru di Indonesia, PT. Gramedia : Jakarta

Yuspratiwi, I. 1990. Hubungan antara Locus of Control dengan Disiplin Kerja Wiraniaga pada Wiraniaga Obat-obatan di DIY. Skripsi. (Tidak diterbitkan) Yogyakarta : Fakultas Psikolog UGM

Werther, dan Davis, Keith, 1996, Human Resource and Personnel Management, 5 Th ed., McGrawHill, New York 